\title{
PENGARUH KOMUNIKASI DAN PARTISIPASI MASYARAKAT TERHADAP IMPLEMENTASI METODA CLTS (COMMUNITY LED TOTAL SANITATION) \\ (Studi : Penggunaan Pendekatan CLTS di Desa Gunung Bunder II, Kecamatan Pamijahan, Kabupaten Bogor, Propinsi Jawa Barat)
}

\author{
Kemas Vivi Andayani \\ Dosen Fakultas Ekonomi Universitas Pamulang \\ Email : dosen01342@unpam.ac.id
}

\begin{abstract}
ABSTRAK
Penelitian ini bertujuan untuk mengetahui pengaruh komunikasi dan partisipasi masyarakat terhadap implementasi metoda Community Led Total Sanitation (CLTS) di Desa Gunung Bunder II, Kecamatan Pamijahan, Kabupaten Bogor, Propinsi Jawa Barat.

Penelitian yang dilakukan penulis penelitian kuantitatif yang bersifat deskriptip analitis dengan menggunakan metode survey. Variabel yang diteliti adalah variabel independent yaitu Komunikasi (X1) dan Partisipasi Masyarakat (X2) mempengaruhi Implementasi Metoda CLTS (Y) sebagai variabel dependent.

Populasi dalam penelitian ini adalah warga Desa Gunung Bunder II dan sampel yang diambil sebanyak 53 responden. Hasil penelitian menunjukkan : (1) terdapat pengaruh komunikasi terhadap implementasi Community Led Total Sanitation di Desa Gunung Bunder II, yaitu sebesar $0,021 \%$ dan berarti pada taraf signifikan $\alpha=0,05$, (2) terdapat pengaruh partisipasi masyarakat terhadap implementasi Community Led Total Sanitation di Desa Gunung Bunder II, yaitu sebesar 37,6\% dan berarti pada taraf signifikan $\alpha=0,05$, (3) terdapat pengaruh komunikasi dan partisipasi masyarakat terhadap implementasi Community Led Total Sanitation di Desa Gunung Bunder II, yaitu sebesar 67,02\% dan berarti pada taraf signifikan $\alpha=0,05$.
\end{abstract}

Kata kunci : Kompensasi, Partisipasi Masyarakat, Implementasi Metoda CLTS 


\section{PENDAHULUAN}

Pemerintah melalui Peraturan Presiden No. 7 tahun 2005 menetapkan Rencana Pembangunan Jangka Menengah Nasional (Tahun 2004 - 2009). Dalam Program Lingkungan Sehat Pemerintah lingkungan hidup yang lebih sehat, melalui Kabupaten Bogor merupakan salah satu Desa beberapa pokok kegiatan antara lain : Percontohan pelaksanaan CLTS (Community penyediaan sarana air bersih dan sanitasi Led Total Sanitation) di daerah Bogor. Mengapa dasar, pemeliharaan dan pengawasan Desa ini menjadi pilihan pilot projek bagi kualitas lingkungan, pengendalian dampak pelaksanaan CLTS? Karena pada tahun 2002 resiko pencemaran lingkungan dan Desa ini pernah mengalami wabah diare yang pengembangan wilayah sehat.

hebat hingga memakan banyak korban jiwa, Salah satu kegiatan yang telah disepakati yang disebabkan oleh minimnya kesadaran dalam upaya meningkatkan penyehatan masyarakat akan Prilaku Hidup Bersih dan lingkungan khususnya di daerah pedesaan Sehat. Hingga para tokoh-tokoh masyarakat di dilakukan pembangunan dengan Desa Gunung Bunder tersebut berkumpul dan melibatkan masyarakat secara aktif dan membuat kesapakatan untuk mengajukan dan swadaya dengan menggunakan metode bersedia menjadi desa percontohan bagi CLTS (Community Led Total Sanitation) pelaksanaan CLTS (Community Led Total untuk meningkatkan demand masyarakat. Sanitation), dan baru terealisasi pada awal Strategi dengan menggunakan metode tahun 2007.

CLTS (Community Led Total Sanitation) telah didesiminasikan kepada pemerintah daerah dan telah dilakukan ujicoba dibeberapa daerah dengan hasil yang cukup menjanjikan. Strategi ini akan digunakan sebagai pola dasar perencanaan pembangunan sanitasi didaerah khususnya didaerah pedesaan melalui pemberdayaan masyarakat.

CLTS (Community Led Total

Sanitation) adalah sebuah pendekatan dalam usaha perubahan perilaku dan pembangunan sarana sanitasi pedesaan dengan menempatkan masyarakat sebagai perlaku utama kegiatan mulai dari tahap identifikasi masalah, analisa resiko pencemaran lingkungan yang disebabkan buang air besar ditempat terbuka, perencanaan dan pembangunan jamban tanpa bantuan pendanaan dari luar. Apa hasil yang diharapkan, adanya perubahan perilaku masyarakat untuk tidak membuang air besar/berak di sembarang tempat (Free open defecation), Oleh karena itu pada bulan Mei 2005, Indonesia mulai menguji coba CLTS (Community Led Total Sanitation) di beberapa wilayah,
Sanitasi Total yang dipimpin oleh masyarakat melibatkan fasilitasi atas suatu proses untuk menyemangati serta memberdayakan masyarakat setempat untuk menghentikan buang air besar di tempat terbuka dan membangun serta menggunakan jamban. Melalui penggunaan Partisipatory Rural Appraisal para anggota masyarakat menganalisa profil sanitasinya masing - masing termasuk luasnya buang air besar di tempat terbuka serta penyebaran kontaminasi dari kotoran-ke-mulut yang mempengaruhi dan memperburuk keadaan setiap orang. Pendekatan CLTS (Community Led Total Sanitation) menimbulkan perasaan jijik dan malu di antara peserta PRA. Secara kolektif mereka menyadari dampak buruk dari buang air besar di tempat terbuka: bahwa mereka akan selamanya saling memakan kotorannya masing - masing apabila buang air besar di tempat terbuka masih berlangsung. Kesadaran ini menggerakkan mereka untuk memprakarsai tindakan lokal secara kolektif guna memperbaiki keadaan sanitasi di dalam komunitas. 
$\begin{array}{ccl} & \text { Dalam CLTS } & \text { (Community Led } \\ \text { Total } & \text { Sanitation) } & \text { fasilitator tidak }\end{array}$ memberikan solusi. Namun ketika metode telah diterapkan (proses pemicuan telah dilakukan) dan masyarakat sudah terpicu sehingga diantara mereka sudah ada keinginan untuk berubah tetapi masih ada kendala yang mereka rasakan misalnya kendala teknis, ekonomi, budaya, dan lainlain maka fasilitator mulai memotivasi mereka untuk mencapai perubahan kearah yang lebih baik, misalnya dengan cara memberikan alternative pemecahan masalah-masalah terebut. Tentang usaha atau alternative mana yang akan digunakan semuanya harus dikembalikan kepada masyarakat tersebut.

\section{TINJAUAN PUSATAKA}

\section{A. Kajian Teori Relevan}

1. Komunikasi menurut Murphy

$(1957: 5)$

komunikasi adalah seluruh proses yang diperlukan untuk mencapai pikiran-pikiran yang dimaksud oleh orang lain (Communication is the whole process used in reaching other minds).

\section{Partisipasi Masyarakat}

Davis dan Newstrom (998: 229-230) mengemukakan pendapat Partisipasi merupakan keterlibatan mental dan emosional seseorang dalam suatu kelompok, yang mendorong mereka untuk memberikan kontribusi kepada tujuan kelompok, dan berbagai tanggung jawab dalam pencapaian tujuan.

\section{Metoda CLTS}

Community Led Total Sanitation (CLTS) adalah sebuah pendekatan dalam usaha perubahan perilaku dan pembangunan sarana sanitasi pedesaan dengan menempatkan masyarakat sebagai pelaku utama kegiatan mulai dari tahap identifikasi masalah, analisa resiko pencemaran lingkungan yang disebabkan buang air besar ditempat terbuka, perencanaan dan pembangunan jamban tanpa bantuan pendanaan dari luar. Apa hasil yang diharapkan, adanya perubahan perilaku masyarakat untuk tidak membuang air besar di sembarang tempat (Free open defecation).

\section{B. Model Penelitian.}

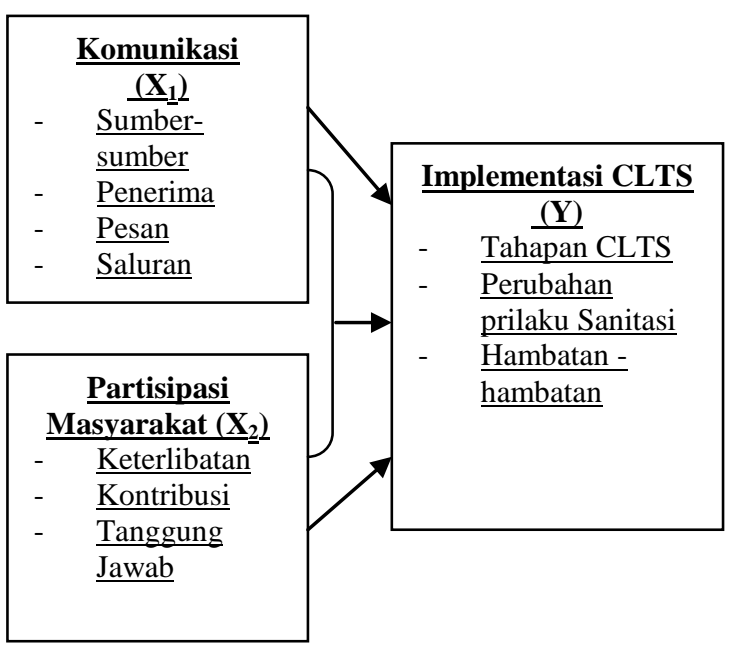

C. Hipotesis Penelitian

1. Diduga terdapat pengaruh signifikan dan positif dari Komunikasi terhadap implementrasi CLTS

2. Diduga terdapat pengaruh signifikan dan positif dari Partisipasi Masyarakat terhadap implementrasi CLTS

3. Diduga terdapat pengaruh signifikan dan positif dari Komunikasi dan Partisipasi Masyarakat terhadap implementrasi CLTS

\section{METODOLOGI PENELITIAN}

A. Penelitian ini dilaksanakan di Desa Gunung Bunder II, Kecamatan Pamijahan, Kabupaten Bogor, Propinsi Jawa Barat. Dalam pelaksanaan penelitian, penulis mengumpulkan data melalui penyebaran kuesioner kepada warga Desa Gunung Bunder II, Kecamatan Pamijahan, Kabupaten Bogor, Propinsi Jawa Barat

B. Desain penelitian yang digunakan dalam kegiatan ini adalah jenis penelitian kuantitatif yang bersifat deskriptif analitis. Kuantitatif dalam pengertian bahwa dalam penelitian ini dilakukan pengujian statistik, 
khususnya untuk mengatur seberapa besar kaitan atau kekuatan hubungan di antara variabel-variabel yang diteliti. Bersifat deskriptif analitis maksudnya bahwa penelitian ini tidak saja ingin menggambarkan secara jelas deskripsi mengenai variabel bebas dan variabel terikat yang digunakan dalam penelitian ini, tetapi juga mencoba menjelaskan hubungan korelasional diantara variabelvariabel tersebut

\section{Populasi dan Sampel}

Populasi dari penelitian ini adalah seluruh masyarakat di Desa Gunung Bunder, Kecamatan Pamijahan, Kabupaten Bogor, Propinsi Jawa Barat. Dengan menggunakan Rumus Slovin (Rachmat Kriyantono, 2006:168) sebagai dasar perhitungan, dengan tingkat kesalahan yang ditolerir adalah 15\% maka jumlah sample yang diperlukan adalah 44 sampel. Untuk mengantisipasi adanya sampel yang tidak valid atau tidak realiabel, jumlah sampel dilebihkan $20 \%$ dari target yang seharusnya yaitu 44 sampel, sehingga total sampel menjadi 53 sampel

D. Variabel Penelitian

1) Variabel Bebas (independent variable):

Variabel bebas adalah variable yang menjadi sebab timbulnya atau berubahnya variabel terikat. Variabel in sering disebut sebagai variable stimulus, input, predictor atau antecedent. Dengan demikian variable bebas adalah variable yang mempengaruhi (Sugiyono, 2006:3).

Variabel bebas yang digunakan dalam penelitian ini, yaitu:

$\left(\mathrm{X}_{1}\right) \quad$ : Komunikasi

$\left(\mathrm{X}_{2}\right) \quad$ : Partisipasi Masyarakat

2) Variabel Terikat (dependent variable):

Variabel terikat adalah yang dipengaruhi atau yang menjadi akibat karena, adanya variable bebas (independent variable), sering juga disebut sebagai variable respon, output, criteria, konsekuen (Sugiyono, 2006:3).

Variable terikat yang digunakan dalam penelitian ini, yaitu:

( Y ) : Implementasi CLTS

E. Tehnik Pengumpulan Data

Teknik pengumpulan data primer (langsung) dan sekunder (tidak langsung) yang digunakan dalam penelitian ini

F. Analisis Data dan Pengujian Hipotesis

1. Analisis Data

2. Pengujian Validitas

Instrumen Penelitian

Uji validitas dilakukan untuk melihat atau menguji tingkat keandalan atau kesahahihan suatu alat ukur, sebagaimana yang dikemukakan oleh Arikunto (1995:63).

$\mid r$ hitung $=\frac{n\left(\sum X Y\right)\left(\sum X\right) \cdot\left(\sum Y\right)}{\sqrt{\left\{n \cdot \sum X^{2}\left(\sum X\right)^{2}\right\} \cdot\left\{n \cdot \sum Y^{2}\left(\sum Y\right)^{2}\right.}}$

Nilai korelasi Pearson Product Moment (r), nilainya berkisar antara $(-1 \leq \mathrm{r} \leq+1)$. Apabila nilai $r=-1$ artinya korelasinya negatif sempurna; $r=0$ artinya tidak ada korelasi dan $r=1$ berarti korelasi sangat kuat.

1) Pengujian Normalitas

Uji normalitas bertujuan untuk mengetahui distribusi data dalam variabel yang akan digunakan dalam penelitian

a. Analisis Regresi Linier mengetahui bentuk hubungan fungsional antar variabel bebas (independent variable), dengan variabel tidak bebas (dependence variable)

Regresi Linier Ganda yaitu persamaan regresi yang terdiri dari beberapa variabel bebas dan sebuah variabel tak bebas

$$
\mathrm{Y}=\mathrm{a}+\mathrm{b}_{1} \mathrm{X}_{1}+\mathrm{b}_{2} \mathrm{X}_{2}
$$


b. Analisis Korelasi (Pearson Product Moment)

mengetahui derajat (tingkat keeratan) hubungan linier antar 2 buah variabel atau lebih.

$\mathrm{r} x y=\frac{\mathrm{n}\left(\sum \mathrm{XY}\right)\left(\sum \mathrm{X}\right) \cdot\left(\sum \mathrm{Y}\right)}{\sqrt{\left\{\mathrm{n} \cdot \sum \mathrm{X}^{2}\left(\sum \mathrm{X}\right) 2\right\} \cdot\left\{\mathrm{n} \cdot \sum \mathrm{Y}^{2}\left(\sum \mathrm{Y}\right)^{2}\right\}}}$

2) Rancangan Uji Hipotesis

a. Hipotesis alternatif $1: \mathbf{H}_{\mathbf{1}}: \boldsymbol{\beta}_{1} \neq \mathbf{0}$

Terdapat peranan yang signifikan komunikasi terhadap implementasi CLTS

Hipotesis nol : $\mathbf{H}_{\mathbf{1}}: \boldsymbol{\beta}_{1}=\mathbf{0}$

Tidak terdapat peranan yang signifikan komunikasi terhadap implementasi CLTS

Kriteria : Jika $\mathrm{t}_{\text {hitung }}>\mathrm{t}_{\text {tabel, }}$, maka Ho ditolak dan $\mathrm{H}_{1}$ diterima

b. Hipotesis alternatif 2: $\mathbf{H}_{\mathbf{1}}: \beta_{2} \neq \mathbf{0}$

Terdapat peranan yang signifikan partisipasi masyarakat terhadap implementasi CLTS

Hipotesis nol : $\mathbf{H}_{\mathbf{1}}: \beta_{2}=\mathbf{0}$

Tidak terdapat peranan yang signifikan partisipasi masyarakat terhadap implementasi CLTS

Kriteria : Jika $\mathrm{t}_{\text {hitung }}>\mathrm{t}_{\text {tabel}}$, maka Ho ditolak dan $\mathrm{H}_{1}$ diterima

c. Hipotesis alternatif $3: \mathbf{H}_{\mathbf{1}}: \beta_{1}=\beta_{2} \neq$ 0 Terdapat peranan yang signifikan komunikasi dan partisipasi masyarakat secara bersama-sama terhadap implementasi CLTS

Hipotesis nol : $\mathbf{H}_{\mathbf{1}}: \beta_{1}=\beta_{2}=\mathbf{0}$

Tidak terdapat peranan yang signifikan komunikasi dan partisipasi masyarakat terhadap implementasi CLTS

Kriteria : Jika $\mathrm{T}_{\text {hitung }}>\mathrm{T}_{\text {tabel}}$, maka Ho ditolak dan $\mathrm{H}_{1}$ diterima
III. HASIL PENELITIAN DAN PEMBAHASAN

A. Hasil Analisis Data dan Pengujian Hipotesis

1. Uji Validitas

Hasil uji masing-masing variabel dari 53 responden

a) Variabel Komunikasi (X1) digunakan 14 pertanyaan yang disebarkan ke 53 responden dengan hasil sebagai barikut:

\begin{tabular}{|c|c|c|c|}
\hline No. Item & Nilai $\mathbf{r}_{\text {hitung }}$ & Nilai $\mathbf{r}_{\text {tabel }}$ & Keterangan \\
\hline 1 & 0,7877 & 0,361 & Valid \\
\hline 2 & 0,7236 & 0,361 & Valid \\
\hline 3 & 0,6718 & 0,361 & Valid \\
\hline 4 & 0,6765 & 0,361 & Valid \\
\hline 5 & 0,7557 & 0,361 & Valid \\
\hline 6 & 0,5645 & 0,361 & Valid \\
\hline 7 & 0,7880 & 0,361 & Valid \\
\hline 8 & 0,7500 & 0,361 & Valid \\
\hline 9 & 0,6452 & 0,361 & Valid \\
\hline 10 & 0,5724 & 0,361 & Valid \\
\hline 11 & 0,5272 & 0,361 & Valid \\
\hline 12 & 0,5789 & 0,361 & Valid \\
\hline 13 & 0,5108 & 0,361 & Valid \\
\hline 14 & 0,6773 & 0,361 & Valid \\
\hline
\end{tabular}

b) Variabel Partisipasi Masyarakat (X2) digunakan 12 pertanyaan yang disebarkan ke 53 responden dengan hasil sebagai barikut:

\begin{tabular}{|c|c|c|c|}
\hline No. Item & Nilai $\mathbf{r}_{\text {hitung }}$ & Nilai $\mathbf{r}_{\text {tabel }}$ & Keterangan \\
\hline 1 & 0,7089 & 0,361 & Valid \\
\hline 2 & 0,6736 & 0,361 & Valid \\
\hline 3 & 0,6841 & 0,361 & Valid \\
\hline 4 & 0,6959 & 0,361 & Valid \\
\hline 5 & 0,5859 & 0,361 & Valid \\
\hline 6 & 0,6025 & 0,361 & Valid \\
\hline 7 & 0,4289 & 0,361 & Valid \\
\hline 8 & 0,5105 & 0,361 & Valid \\
\hline 9 & 0,8176 & 0,361 & Valid \\
\hline 10 & 0,7864 & 0,361 & Valid \\
\hline 11 & 0,7139 & 0,361 & Valid \\
\hline 12 & 0,3635 & 0,361 & Valid \\
\hline
\end{tabular}

c. Variabel Implementasi CLTS (Y) digunakan 14 pertanyaan yang disebarkan ke 53 responden dengan hasil sebagai barikut:

\begin{tabular}{|c|c|c|c|}
\hline No. Item & Nilai $\mathbf{r}_{\text {hitung }}$ & Nilai $\mathbf{r}_{\text {tabel }}$ & Keterangan \\
\hline 1 & 0,6760 & 0,361 & Valid \\
\hline 2 & 0,5623 & 0,361 & Valid \\
\hline 3 & 0,6760 & 0,361 & Valid \\
\hline 4 & 0,6146 & 0,361 & Valid \\
\hline 5 & 0,5466 & 0,361 & Valid \\
\hline 6 & 0,6760 & 0,361 & Valid \\
\hline 7 & 0,6330 & 0,361 & Valid \\
\hline 8 & 0,7333 & 0,361 & Valid \\
\hline 9 & 0,6468 & 0,361 & Valid \\
\hline 10 & 0,6760 & 0,361 & Valid \\
\hline 11 & 0,5224 & 0,361 & Valid \\
\hline 12 & 0,6760 & 0,361 & Valid \\
\hline
\end{tabular}




\begin{tabular}{|l|l|l|l|}
\hline 13 & 0,3545 & 0,361 & Valid \\
\hline 14 & 0,5446 & 0,361 & Valid \\
\hline
\end{tabular}

\section{Uji Normalitas}

Hasil uji normalitas terhadap variabel $\mathrm{X}_{1}$ (Komunikasi), variabel $\mathrm{X}_{2}$ (Partisipasi Masyarakat) dan variabel Y (Implementasi CLTS) memperlihatkan bahwa data terdistribusi secara normal karena menghasilkan nilai Skewness yang mendekati nol, diketahui bahwa:

- $\quad$ Nilai Skewness variabel Komunikasi adalah : 1,041

- Nilai Skewness variabel Partisipasi Masyarakat adalah $\quad: 0,884$

- Nilai Skewness variabel Implementasi CLTS adalah : 0,152

\begin{tabular}{|l|l|r|r|r|r|}
\hline \multicolumn{7}{|c|}{ Descriptive Statistics } \\
\hline N & Komunikasi & $\begin{array}{c}\text { Partisipasi } \\
\text { Masyarakat }\end{array}$ & $\begin{array}{l}\text { Implementasi } \\
\text { CLTS }\end{array}$ & $\begin{array}{c}\text { Valid N } \\
\text { (listwise) }\end{array}$ \\
\hline Range & Statistic & 53 & 53 & 53 & \\
\hline Minimum & Statistic & 27.27 & 27.27 & 17.14 & \\
\hline Maximum & Statistic & 72.73 & 72.73 & 71.43 & \\
\hline Sum & Statistic & 100.00 & 100.00 & 88.57 & \\
\hline Mean & Statistic & 4443.63 & 4449.13 & 4194.31 & \\
& Statistic & 83.8421 & 83.9458 & 79.1379 & \\
& Std. Error & .86049 & .81334 & .56326 & \\
\hline Std. Deviation & Statistic & 6.26449 & 5.92122 & 4.10062 & \\
\hline Variance & Statistic & 39.244 & 35.061 & 16.815 & \\
\hline Skewness & Statistic & 1.041 & .884 & .152 & \\
& Std. Error & .327 & .327 & .327 & \\
\hline Kurtosis & Statistic & .549 & .424 & .397 & \\
& Std. Error & .644 & .644 & .644 & \\
\hline
\end{tabular}

Berikut terlihat data yang terdistribusi secara normal, memiliki kemiringan yang cenderung seimbang, hal ini terlihat pada gambar histogram dengan curva yang terdistribusi normal sebagai berikut :

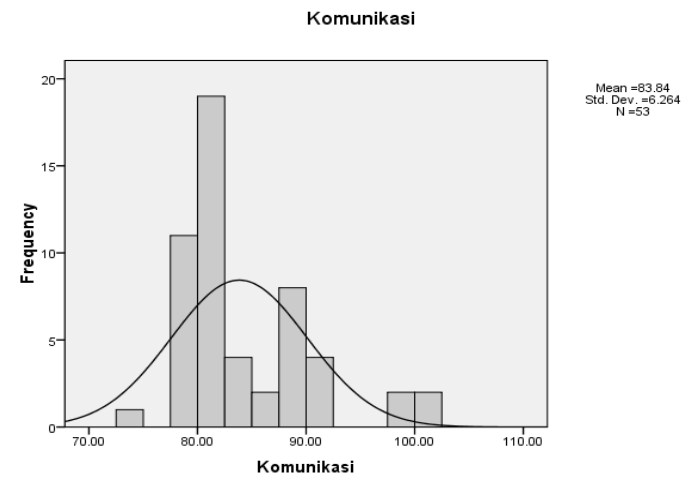

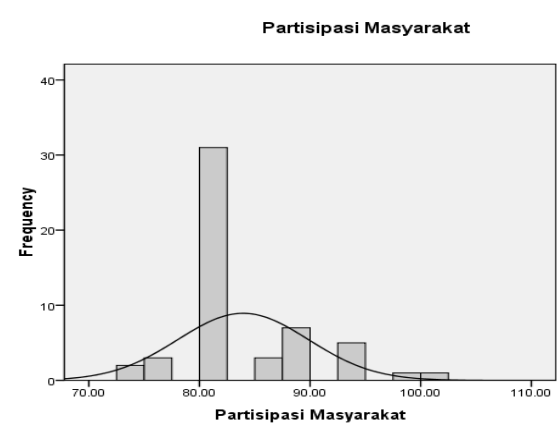

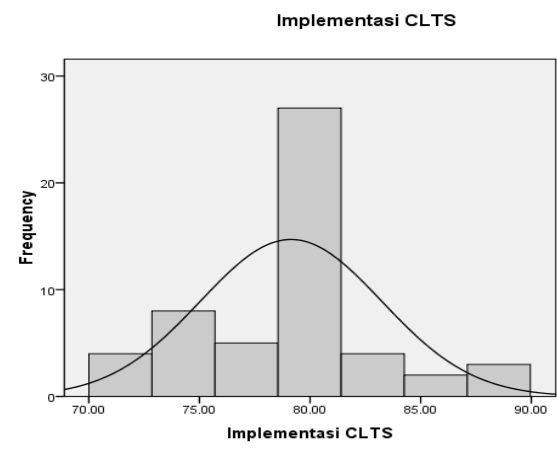

Mean $=79.14$
Std. Deve
$\mathbb{N}=5.4 .101$

\section{Deskripsi Data}

Hasil pengolahan data terhadap 3 variabel $\mathrm{X}_{1}$ (Komunikasi), $\mathrm{X}_{2}$ (Partisipasi Masyarakat) dan variabel Y (Implementasi CLTS) menghasilkan deskripsi statistik seperti berikut :

\begin{tabular}{|l|l|r|r|r|r|}
\hline \multicolumn{7}{|c|}{ Descriptive Statistics } \\
\hline N & Komunikasi & $\begin{array}{c}\text { Partisipasi } \\
\text { Masyarakat }\end{array}$ & $\begin{array}{l}\text { Implementasi } \\
\text { CLTS }\end{array}$ & $\begin{array}{c}\text { Valid N } \\
\text { (listwise) }\end{array}$ \\
\hline Range & Statistic & 53 & 53 & 53 & \\
\hline Minimum & Statistic & 27.27 & 27.27 & 17.14 & \\
\hline Maximum & Statistic & 72.73 & 72.73 & 71.43 & \\
\hline Sum & Statistic & 100.00 & 100.00 & 88.57 & \\
\hline Mean & Statistic & 4443.63 & 4449.13 & 4194.31 & \\
& Statistic & 83.8421 & 83.9458 & 79.1379 & \\
& Std. Error & .86049 & .81334 & .56326 & \\
\hline Std. Deviation & Statistic & 6.26449 & 5.92122 & 4.10062 & \\
\hline Variance & Statistic & 39.244 & 35.061 & 16.815 & \\
\hline Skewness & Statistic & 1.041 & .884 & .152 & \\
& Std. Error & .327 & .327 & .327 & \\
\hline Kurtosis & Statistic & .549 & .424 & .397 & \\
& Std. Error & .644 & .644 & .644 & \\
\hline
\end{tabular}

\section{Analisis Korelasi dan Regresi}

Hasil pengolahan data terhadap 3 variabel $\mathrm{X}_{1}$ (Komunikasi), $\mathrm{X}_{2}$ (Partisipasi Masyarakat) dan variabel Y (Implementasi CLTS) menghasilkan analisa korelasi dan regresi sebagai berikut dengan koefisien korelasi dihitung menggunakan rumus Pearson Produk Momen, untuk data sebanyak $\mathrm{N}=53$ 


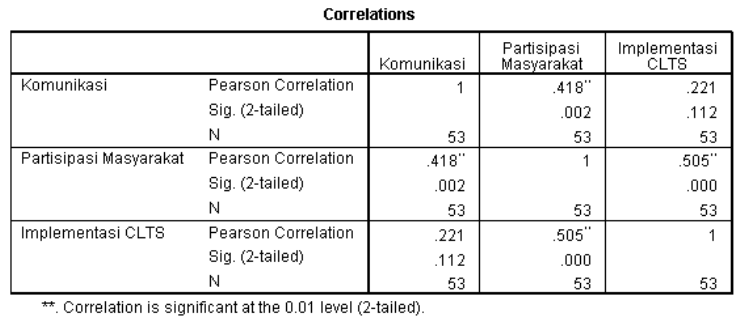

Nilai koefisien korelasi antara variabel penyebab (eksogenous), yaitu Komunikasi $\left(\mathrm{X}_{1}\right)$ dengan variabel akibat (endogenous) yaitu Implementasi CLTS (Y) adalah $\mathrm{r}$ $\mathrm{yx} 1=0,221$

Nilai koefisien korelasi antara variabel (eksogenous), yaitu Partisipasi Masyarakat $\left(\mathrm{X}_{2}\right)$ dengan variabel akibat (endogenous) yaitu Implementasi CLTS (Y) adalah $\mathrm{r}$ $\mathrm{yx}_{2}=0,505$

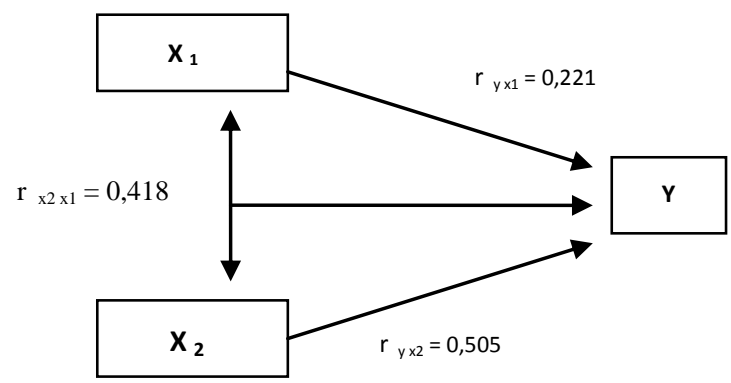

Karena nilai Asym.Sig.(P-value) untuk :

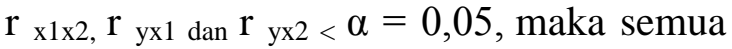
nilai koefisien korelasi berarti pada taraf siginifikan $\alpha=0,05$. Koefisien korelasi antara variabel $\mathrm{X}_{1}$, variabel $\mathrm{X}_{2}$ dan variabel $\mathrm{Y}$

Model Summary yang didapat :

\begin{tabular}{|c|c|c|c|c|}
\hline \multicolumn{5}{|c|}{ Model Summary } \\
\hline Mode & $\mathrm{R}$ & R Square & $\begin{array}{l}\text { Adjusted R } \\
\text { Square }\end{array}$ & $\begin{array}{l}\text { Std. Error of } \\
\text { the Estimate }\end{array}$ \\
\hline 1 & $.505^{=}$ & .255 & .225 & 3.60981 \\
\hline
\end{tabular}

- Nilai koefiesien korelasi berganda dari variabel predictor Komunikasi dan Partisipasi Masyarakat, terhadap variabel tak bebas (dependen) Implementasi CLTS, adalah $\mathrm{R}=$ 0,505

Sedangkan nilai koefisien determinansi $\mathrm{R} 2=0,255$
- Nilai koefisien korelasi tersebut berarti pada taraf signifikan $\alpha=0,05$, sebab nilai Sig. F. Change $=0,001<$ $0,05=\alpha$

Ini berarti bahwa $25,5 \%$ Implementasi CLTS dipengaruhi oleh Komunikasi dan Partisipasi Masyarakat.

Sisanya sebesar $100 \%-25,5 \%=74,5 \%$ ditentukan oleh faktor lain (faktor luar)

Tabel Anova

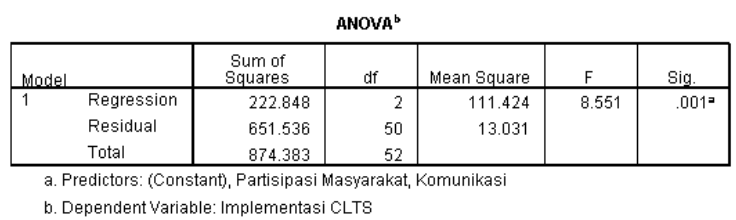

b. Dependent Variable: Implementasi CLTS

Analisa menginterpretasikan hal berikut:

- $\quad$ Nilai F hitung $=8,551$

- Berarti pada taraf signifikan 0,05 karena probabilitas $0,001<0,05$

- Dengan demikian model regresi dapat dipakai untuk memprediksi kualitas Implementasi CLTS

Dengan melihat tabel, pada taraf signifikan $\alpha=0,05$ dengan derajat kebebasan pembilang 2, derajat kebebasan penyebut 50 nilai $\mathrm{F}$ tabel $=3,18$

- Dengan membandingkan nilai F hitung dengan $\mathrm{F}$ tabel, maka $\mathrm{F}$ hitung $=8,55>\mathrm{F}$ tabel $=3,18$

- $\quad$ Sesuai dengan kriteria pengujian uji $\mathrm{F}$, bila $\mathrm{F}$ hitung $>\mathrm{F}$ tabel, maka signifikan.

\section{tabel Coefficients}

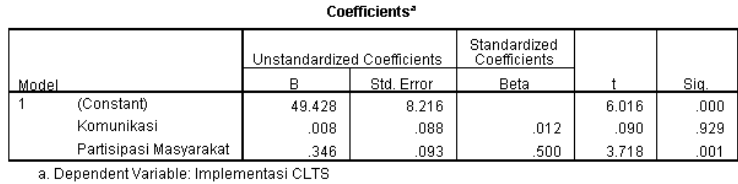

- Koefisien-koefisien persamaan regresi adalah sebagai berikut:

- Koefisien Konstanta

$$
=49,42
$$

- Koefisien variabel Komunikasi $=0,008$

- Koefisien variabel Partisipasi Masyarakat $\quad=0,346$ 
Jadi persamaan regresinya adalah Implementasi CLTS $=49.428+$ 0,008 Komunikasi $+0,346$ Partisipasi Masyarakat

Berarti pada taraf signifikansi $\alpha=$ 0,05 ; sebab nilai $\mathrm{Sig}=0,000<0,05$

\section{Hipotesis}

Hipotesis 1 dari penelitian ini adalah : terdapat peranan yang signifikan Komunikasi terhadap Implementasi CLTS. Hipotesis tersebut dijabarkan menjadi hipotesis statistik, sebagai berikut : $\mathrm{H}_{0}: \mathrm{P}$ ${ }_{\mathrm{xy} 1}=0$ lawannya $\mathrm{H}_{1}: \mathrm{P}_{\mathrm{xy} 1} \neq 0$. Nilai Sig untuk coefisien jalur antara variabel eksogenous Komunikasi (X1) dengan variabel endogenous Implementasi CLTS (Y) adalah 0,012, karena Sig $=0,929>$ $0,05=\alpha$ maka Ho diterima pada taraf signifikansi $\alpha=0,05$. berarti bahwa

hipotesis penelitian 1 ditolak pada taraf signifikansi $\alpha=0,05$ dengan kata lain ada peranan langsung yang signifikan dari komunikasi $\left(\mathrm{X}_{1}\right)$ terhadap Implementasi CLTS (Y)

Hipotesis 2 dari penelitian ini adalah : terdapat peranan yang signifikan Partisipasi Masyarakat terhadap Implementasi CLTS. Hipotesis tersebut dijabarkan menjadi hipotesis statistik, sebagai berikut : $\mathrm{H}_{0}: \mathrm{P}_{\mathrm{xy} 2}=0$ lawannya $\mathrm{H}_{1}: \mathrm{P}_{\mathrm{xy} 2} \neq 0$. Nilai Sig untuk coefisien jalur antara variabel eksogenous Partisipasi Masyarakat $\left(\mathrm{X}_{2}\right)$ dengan variabel endogenous Implementasi CLTS (Y) adalah 0,500, karena Sig $=0,004<$ $0,05=\alpha$ maka Ho ditolak pada taraf signifikansi $\alpha=0,05$. Ini berarti bahwa hipotesis penelitian 2 diterima pada taraf signifikansi $\alpha=0,05$ dengan kata lain tidak ada peranan langsung yang signifikan dari Partisipasi Masyarakat $\left(\mathrm{X}_{2}\right)$ terhadap Implementasi CLTS (Y)

Hipotesis 3 dari penelitian ini adalah : terdapat peranan yang signifikan Komunikasi dan Partisipasi Masyarakat terhadap Implementasi CLTS. Hipotesis tersebut dijabarkan menjadi hipotesis statistik, sebagai berikut : $\mathrm{H}_{0}: \rho_{\mathrm{yx} 1 \times 1}=0$ lawannya $\mathrm{H}_{1}: \rho_{\mathrm{yx} 1 \times 2} \neq 0$. Nilai koefisien korelasi berganda antara Komunikasi dan Partisipasi Masyarakat secara bersamasama terhadap Implementasi CLTS adalah sebesar $R_{\mathrm{yx} 1 \times 2}=0,505$. Nilai koefisien korelasi ini berarti pada taraf signifikansi $\alpha$ $=0,05$, sebab nilai Sig $(1$-tailed $)=0,001<$ $\alpha=0,05$. Berarti bahwa Ho ditolak pada taraf signifikansi $\alpha=0,05$

\section{Pembahasan}

Hasil analisis korelasi, analisis regresi dana analisis jalur dapat disimpulkan bahwa pengaruh komunikasi terhadap implementasi CLTS adalah sebesar $0,021 \%$, dan tidak berarti pada taraf signifikant $\alpha=0,05$.

Hasil analisis korelasi, analisis regresi dana analisis jalur dapat disimpulkan bahwa pengaruh partisipasi masyarakat terhadap implementasi CLTS adalah sebesar $37,6 \%$, dan berarti pada taraf signifikan $\alpha=0,05$.

Hasil analisis korelasi, analisis regresi dan analisis jalur dapat disimpulkan bahwa pengaruh Komunikasi dan Partisipasi Masyarakat terhadap implementasi CLTS, di Desa Gunung Bunder II, Kecamatan Pamijahan, Kabupaten Bogor, Propinsi Jawa Barat sebesar $67,02 \%$ dan berarti pada taraf signifikan $\alpha=0,05$.

\section{KESIMPULAN DAN SARAN}

A. Kesimpulan

1) Terdapat pengaruh komunikasi terhadap implementasi Community Led Total Sanitation di Desa Gunung Bunder II, yaitu sebesar $0,021 \%$ dan berarti pada taraf signifikan $\alpha=0,05$

2) Terdapat pengaruh partisipasi masyarakat terhadap implementasi Community Led Total Sanitation di Desa Gunung Bunder II, yaitu sebesar 37,6\% dan berarti pada taraf signifikan $\alpha=0,05$

3) Terdapat pengaruh komunikasi dan partisipasi masyarakat terhadap implementasi Community Led Total 
Sanitation di Desa Gunung Bunder II, yaitu sebesar $37,62 \%$ dan berarti pada taraf signifikan $\alpha=0,05$.

\section{B. Saran}

1) Selain variabel komunikasi dan partisipasi masyarakat yang secara teoritis diduga mempengaruhi keberhasilan metode CLTS di Desa Gunung Bunder II, Kecamatan Pamijahan, Kabupaten Bogor, Propinsi Jawa Barat perlu pula diteliti faktor-faktor lain yang mempengaruhinya.

2) Disarankan instansi yang terkait sebagai pihak yang bertanggung jawab dalam keberhasilan metode CLTS di Desa Gunung Bunder II, Kecamatan Pamijahan, Kabupaten Bogor, Propinsi Jawa Barat dapat lebih meningkatkan peranan komunikasi dan partisipasi masyarakat yang sudah baik selama ini, dengan demikian tujuan Pemerintah bagi Program Lingkungan Sehat yang salah satunya adalah upaya meningkatkan penyehatan lingkungan khususnya di daerah pedesaan yang dilakukan pembangunannya dengan melibatkan masyarakat secara aktif dan swadaya dengan menggunakan metode Community Led Total Sanitation (CLTS) dapat meningkatkan demand masyarakat.

\section{DAFTAR PUSTAKA}

Sugiyono, 2007, Statistik untuk Penelitian, Bandung : Alfabeta

C, Trihendardi, 2007, Langkah Mudah Menguasai Analis Statistik Menggunakan SPSS 15, Yogyakarta : ANDI

Ruslan, Rosay, 2004, Metoda Penelitian Public Relations dan Komunikasi, Raja Grafindo Persada

Drs. Lg. Wursasnto, 1983, Etika Komunikasi Kantor, Kanisius
Sugiyono, 2004, Metode Penelitian Bisnis, Bandung : Alfabeta

Safrul, 2002, Pemberdayaan Masyarakat melalui program Community based activites dealing with the economic crisis (CBES) studi deskriptif pelaksanaan program CBES di Kelurahan Jelambar Kecamatan Grogol, Jakarta : Universitas Indonesia

Ndraha, Talizduhu, 1935, Pengantar Teori Pengembangan Sumber Daya Manusia, Jakarta : Rineka Cipta

Bianda, Luhur, 1970, Partisipasi Masyarakat dalam Pengembangan Pariwisata Suatu Studi terhadap Partisipasi Masyarakat, Jakarta : Universitas Indonesia

Pajajaran, Universitas, 1972, Laporan Survey tentang Masyarakat Dieng Plato dan sekitarnya kemungkinan partisipasi masyarakat terhadap proyek pembangunan, Bandung : jurusan antropologi, Fakultas Sastra universitas Pajajaran

Wright, Charles, Rakhmat, 1988, Sosiologi Komunikasi Massa, Bandung : 1988

Jalaluddin, Rakhmat, 1949, Metode Penelitian Komunikasi, Bandung : Remaja

Nawawi, Hadari, Haji, 1941, Metode Penelitian bidang Sosial, Bandung : Remadja

Moore, Frazier, 1987, Hubungan Masyarakat, Prinsip, Kasus dan Masalah , Bandung : Remadja Rosdakarya

Mulyana, Deddi, DR, Jalaluddin Rakhmat, 2003, Komunikasi Antar Budaya, Rosda 
Rakmat, Jalaluddin, MSc, 2003, Psikologi Komunikasi, Remaja Rosdakarya

Rakmat, Jalaluddin, MSc, 2002, Metode

Penelitian Komunikasi, Remaja Rosdakarya

Waluyo, S.Sos, Msi. 2007, Manajemen Publik (konsep, aplikasi dan implementasinya dalam pelaksanaan otonomi daerah, CV Mandar Maju

Miarso, Yusuhadi, 1984, Teknology Komunikasi Pendidikan Pengertian dan Penerapannya di Indonesia, Pustekkom Dikbud dan CV Rajawali

Uchjana, Onong, Effendy, Prof, Drs, MA, 1993, Dinamika Komunikasi, Remaja Rosdakarya

Suhendra, 2005, Peranan Birokrasi Dalam Pemberdayaan Masyarakat, Bandung : Alfabeta

Bungin, Burhan, Prof, Dr, HM, Msi, 2007, Penelitian Kualitatif, Kencana Prenada Media Group

Hanafi, Abdillah, Drs, 1986, Memasyarakatkan Ide-Ide Baru, Surabaya : Usaha Nasional

Arikunto,Suharsini, 1993, Prosedur Penelitian Suatu Pendekatan Praktek, Jakarta : Rineka Cipta

Furqon, 2001, Statistika Terapan untuk Penelitian, Bandung : Remaja Karya
Kencana, Inu, Djamaludin Tanjung dan Supardan Modeong, 1999. Ilmu Administrasi Publik. Jakarta : Rineka Cipta

Kriantoro, Rachmat, 2006. Teknik Praktis Riset Komunikasi. Jakarta : Gramedia

Ndraha, Taliziduhu, 1987. Pembangunan Masyarakat. Jakarta : Bina Aksara

Riduwan 2006. Metode dan teknik Menyusun Tesis. Bandung : Alfabeta

Santoso, Singgih, 1999. SPSS Mengolah Data Statistik Secara profesional. Jakarta : PT. Elex Media Komputindo

Sugiyono, 2006. Metode Penelitian Administrasi. Bandung : Alfabeta

Sudjana, Dageng, 1993. Teknik Analisis Regresi \& Korelasi. Bandung : Tarsito

Shatifan, nina, 2007. Facilitators Handbook on Community Led Total Sanitation. WSLIC-2 Project

Kal, Kamal, Dr, 2005. Practical Guide to Triggering Community Led Total Sanitation, World Bank

\section{Dokumen Negara :}

Rencana Kerja Masyarakat Desa Gunung Bunder II, Kecamatan Pamijahan, Kabupaten Bogor, Jawa Barat, periode tahun 2006... 